UDC: $636.4: 636.082 .26$

\title{
INDEX EVALUATION OF PIGS AND DETERMINATION OF SELECTION LIMITS
}

\author{
V. G. Pelikh, S. V. Ushakova, N. L. Pelikh \\ State Higher Educational Institution "Kherson State Agrarian University", \\ 23, Stritenska Str., Kherson, 73006, Ukraine \\ E-mail: ushakovasvetlan@ukr.net
}

Received January 11, 2019 / Received February 10, 2019 / Accepted March 22, 2019

\begin{abstract}
Aim. To determine genetically and mathematically grounded target standards of selecting pigs for future generations. To determine minimal selection limits for pigs to obtain high productivity traits. Methods. Common methods of evaluating the reproductive ability of sows, fattening and meat-fat qualities of progeny. Selection indexes were built by the method of standardized deviations according to M.V. Mykhailov. The target selection limits for animals were determined using the table of Le Roy. Results. Selective-genetic parameters were determined by the main traits of reproductive ability, fattening and meat productivity of pigs. Selection indexes were estimated using the weighting coefficients of the traits for each group of pigs, used as a basis for minimal limits at different intensities of selection. The estimation of local progeny by selection indexes allowed ranging them depending on the level of productivity with the consideration of genotype. At $20 \%$ selection, the minimal value of the reproductive ability index for the control group was 238.7 points. The minimal target threshold while selecting sires by the fattening traits of progeny within the $20 \%$ selection was from 50.57 to 255.65 points for different groups. The minimal value of the index of fattening and meat traits was in the range from 270.05 to 606.94 points. Conclusions. The index estimation of pigs during the crossing allowed ranging them by the values of indexes. Minimal limits of selecting animals were determined and the selection of parental pairs with estimated productivity was optimized: in case of $20 \%$ selection by multiple pregnancy with at least 11 animals, the area of "loin eye" $-30.5-44.5 \mathrm{sq} . \mathrm{cm}$. It would be reasonable to select the animals, the productivity of progeny of which is above the determined limit, for further breeding from 238.70 to 606.94 points.
\end{abstract}

Keywords: selection limits, Pietrain, Duroc, selection index of reproductive ability, selection index of fattening traits, multibreed crossing, meat productivity.

DOI:

\section{INTRODUCTION}

The main goal of modern pig breeding is increasing the genetic potential of animals and obtaining the maximal number of products. Global experience demonstrated that the introduction of the system of breeding and finishing hybrid stock with the organization of the relevant system of estimating animals may be used to increase the profitability of this industry. The increase in the productivity of animals is related to the progress of population in general, and the latter is considerably dependent on the accuracy of estimating genotypes [1-4].

Index estimation is widely used in the whole world. The BLUP method was elaborated in the 1980-s and is

(C) V. G. PELIKH, S. V. USHAKOVA, N. L. PELIKH, 2019 currently used for almost all the animal species. Nearly all the countries estimate pigs using selection indexes, different in their composition. For instance, in Australia the estimation of pigs is conducted at the holdings, the obtained data (average daily gain, fat thickness, live bodyweight at the time of estimation) are used to calculate the index of selection value [5-10]. In Germany (Bavaria), the index estimation includes the indices of the fat thickness at the point of reaching the live bodyweight of 85-95 kg for sows and 130 $150 \mathrm{~kg}$ - for sires. Exterior data are estimated additionally. The animals with the highest index, complying with minimal exterior requirements, are used in further selection work. In the USA, the estimation of a group of progeny for each sire is conducted with the estimated index, in which the trait of fat thickness takes 
$30 \%$, the area of "loin eye" - $10 \%$, average daily gain $30 \%$, meat quality - $20 \%$, composition steadiness $10 \%$ [11-13].

Scientists suggested an approach to estimating animals by the indices of reproductive ability, fattening traits and comprehensive evaluation of finishing and meat traits [14-16]. The structure of these indices is the same for all the breeds and holdings, there are some changes only in average data of productivity in holdings and the estimated actual weight coefficient, which allows using these indices in any country of the world.

It is relevant to estimate the weighing coefficients of traits, composing the index structure separately for each herd (breed). The index estimate allows isolating the best animals in the herd for further use [1].

The selection of parental pairs by the value of progeny index involves a so-called lower limit of development for each trait under selection. The animals, which have reached and exceeded the set minimal limit, are recommended for further reproduction. The minimal selection limit sets minimal requirements to the development of the trait under selection $[1,15]$.

In modern conditions of intense pig breeding, the hybridization system is based on using maternal and paternal breeds for two-breed and multibreed crossing. Thus, our studies were aimed at estimating genetically and mathematically grounded target limits of selecting pigs for further generations. They were used as a basis to select local progeny with the best value of selection index for further increase in productive traits of animals.

\section{MATERIALS AND METHODS}

The investigations were conducted at Freedom Farm Bacon Limited Liability Company, Kherson Region. Purebred pigs of Large White $(\uparrow \mathrm{LW} \times \overbrace{}^{\lambda} \mathrm{LW})$ were used as a control along with local animals for crossing variants of Large White $\times$ Landrace $\left(\uparrow \mathrm{WL} \times{ }^{\lambda} \mathrm{L}\right)$, Duroc $\times$ $\times$ Pietrain $\left(Q \mathrm{D} \times \diamond^{\lambda} \mathrm{P}\right)$ and Pietrain $\times$ Duroc $\left(Q \mathrm{P} \times \diamond^{\lambda} \mathrm{D}\right)$ and their combinations $q(\mathrm{LW} \times \mathrm{L}) \times \widehat{\partial}(\mathrm{D} \times \mathrm{P})$ and $\phi$ $(\mathrm{LW} \times \mathrm{L}) \times \hat{\partial}(\mathrm{P} \times \mathrm{D})$.

The conditions of feeding and keeping were identical for all the groups of animals within each experiment and corresponded to zootechnic norms with the consideration of age, live bodyweight, and physiological state. The animals were fed with concentrates. The gender ratio of animals in groups was $+50 \%$ and $\widehat{\varnothing} 50 \%$, the number of pigs in each group for studies was proportional.
To enhance the efficiency of selecting pigs of different breeds, selection indexes of reproductive, fattening, and finishing and meat traits $\left(\mathrm{J}_{1}-\mathrm{J}_{3}\right)$ were used, which were built by the method of standardized deviations according to M.V. Mykhailov with the consideration of selective-genetic parameters in the estimation of productive traits of pigs:

by the reproductive ability:

$$
\mathrm{J}_{1}=\mathrm{k}_{1}\left(\mathrm{x}_{1}-\overline{\mathrm{x}}_{1}\right)+\mathrm{k}_{2}\left(\mathrm{x}_{2}-\overline{\mathrm{x}}_{2}\right)
$$

where: $\mathrm{k}_{1}-\mathrm{k}_{2}-$ actual weighing coefficients of traits; $\mathrm{x}_{1}$ - multiple pregnancy, animals;

$\mathrm{x}_{2}$ - weight of pen at the moment of weaning, $\mathrm{kg}$;

by fattening traits:

$$
\mathrm{J}_{2}=\mathrm{k}_{1}\left(\overline{\mathrm{x}}_{1}-\mathrm{x}_{1}\right)+\mathrm{k}_{2}\left(\overline{\mathrm{x}}_{2}-\mathrm{x}_{2}\right)
$$

where: $\mathrm{k}_{1}-\mathrm{k}_{3}-$ actual weighing coefficients of traits; $\mathrm{x}_{1}$ - age of reaching the live bodyweight of $100 \mathrm{~kg}$, days;

$\mathrm{x}_{2}$ - expenses for fodder per $1 \mathrm{~kg}$ of gain, fodder units; by finishing and meat traits:

$\mathrm{J}_{3}=\mathrm{k}_{1}\left(\overline{\mathrm{x}}_{1}-\mathrm{x}_{1}\right)+\mathrm{k}_{2}\left(\overline{\mathrm{x}}_{2}-\mathrm{x}_{2}\right)+\mathrm{k}_{3}\left(\overline{\mathrm{x}}_{3}-\mathrm{x}_{3}\right)+\mathrm{k}_{4}\left(\overline{\mathrm{x}}_{4}-\mathrm{x}_{4}\right)$

where: $\mathrm{k}_{1}-\mathrm{k}_{3}$ - actual weighing coefficients of traits; $\mathrm{x}_{1}$ - age of reaching the live bodyweight of $100 \mathrm{~kg}$, days;

$\mathrm{x}_{2}$ - expenses for fodder per $1 \mathrm{~kg}$ of gain, fodder units; $\mathrm{x}_{3}$ - fat thickness above 6-7 thoracic vertebra, mm; $\mathrm{x}_{4}$ - area of "loin eye", sq.cm.

Actual weighing coefficients, included into selection indexes, were estimated by the ratio of the selection weight trait to the selection effect.

The productivity indices of pigs, included to the estimation of selection indexes, were determined by common methods, elaborated by the Institute of Swine Production n.a. O. V. Kvasnytsky, NAAS in 2005. The reproductive ability of sows in terms of multiple pregnancy was estimated by the number of live newborn piglets per littering, the weight of pen at the time of weaning was estimated after 30 days.

The fattening traits of pigs were estimated by the age of reaching the live bodyweight of $100 \mathrm{~kg}$ and the expenses for fodder per $1 \mathrm{~kg}$ of gain.

During the control slaughter of pigs with the live bodyweight of $100 \mathrm{~kg}$, fat thickness was measured 
between 6 and 7 thoracic vertebrae of a cooled semicarcass in vertical position. The area of "loin eye" was determined on the cross section of the longest spine muscle between 1 and 2 loin vertebrae. The contour of a "loin eye" was transferred to the tracing paper to estimate the value of this index, multiplying width by length and coefficient 0.8 .

Young sows and emasculated boars were used while slaughtering four-breed progeny.

To achieve more accurate differentiation of pigs by productivity indices of progeny, target limits of selecting animals were defined by the formula $[15,17]$ :

$$
\mathrm{MTJ}=\mathrm{M}_{\overline{\mathrm{X}}}+\delta \times \mathrm{T}_{\mathrm{R}}
$$

where $\mathrm{M}_{\overline{\mathrm{X}}}-$ average value of the traits in the studied herd; $\mathrm{d}$ - standard deviation for the experimental herd; TR - table value according to Le Roy with the given percentage of animal selection.

\section{RESULTS AND DISCUSSION}

To select highly productive two-breed animals for further use in the crossing, we estimated selection indexes with the weighing coefficients of traits for each group of pigs (Table 1-3).

Constructing three kinds of indexes for estimation and final selection of two-breed pigs by the results of littering and control finishing and slaughter is conditioned by changeable priorities of modern pig breeding, thus, they may be used both in the complex and individually as an independent instrument of estimating the initial parental forms with the purpose of obtaining progeny with desired level of productivity.

In addition, the estimation of animals by indices $\mathrm{J}_{2}$ and $\mathrm{J}_{3}$ is comprehensive, and, depending of the index structure, weighing coefficients for the trait (\%) are different. Their increase in index $\mathrm{J}_{3}$ was observed for meat indices of productivity.

Taking into consideration average values of productivity for the leading groups, we estimated selectivegenetic parameters by the main traits of reproductive ability, finishing and meat productivity.

All the selective-genetic parameters for further indexes were estimated in the same way.

The average values for the herd by the age of reaching the live bodyweight of $100 \mathrm{~kg}$ were in the range of 173.96-183.54 days, by the expenses per $1 \mathrm{~kg}$ of gain - from 3.55 to 3.42 of fodder units. The selection relevance was from $30.98 \%$ in the group $\odot \mathrm{D} \times{ }^{\lambda} \mathrm{P}$ to $49.03 \%$ in pigs of the group $\bigcirc \mathrm{WL} \times \lesssim \mathrm{WL}$.

The average values for the herd in terms of the age of reaching live bodyweight of $100 \mathrm{~kg}$ were in the range of 175.25-180.25 days, in terms of the expenses for fodder per $1 \mathrm{~kg}$ of gain - from 3.55 to 3.50 of fodder units, in terms of fat thickness above 6-7 thoracic vertebra - from 20.50 to $16.25 \mathrm{~mm}$, in terms of the area of "loin eye" - from 33.93 to 40.33 sq.cm. The selection relevance by all the indices was from $2.41 \%$

Table 1. Selective-genetic parameters in the estimation of reproductive ability of sows $(n=44)$

\begin{tabular}{|c|c|c|}
\hline Index & $\begin{array}{c}\text { Multiple } \\
\text { preg- } \\
\text { nancy, } \\
\text { animals }\end{array}$ & $\begin{array}{c}\text { Weight } \\
\text { of pen at } \\
\text { the mo- } \\
\text { ment of } \\
\text { weaning, } \\
\text { kg }\end{array}$ \\
\hline \multicolumn{3}{|l|}{$+\mathrm{WL} \times \widehat{\jmath} \mathrm{WL}$} \\
\hline Average value for the herd & 10.58 & 76.63 \\
\hline Heredity coefficient & 0.16 & 0.30 \\
\hline Selection effect & 0.31 & 3.20 \\
\hline Genetic variability & 0.24 & 3.46 \\
\hline Weighing coefficient for a trait, $\%$ & 57.94 & 42.06 \\
\hline Actual weight coefficient & 188.94 & 13.14 \\
\hline \multicolumn{3}{|l|}{$q \mathrm{WL} \times \overbrace{}^{\lambda} \mathrm{L}$} \\
\hline Average value for the herd & 10.36 & 61.50 \\
\hline Heredity coefficient & 0.16 & 0.3 \\
\hline Selection effect & 0.34 & 7.74 \\
\hline Genetic variability & 0.25 & 3.25 \\
\hline Weighing coefficient for a trait, $\%$ & 36.44 & 63.56 \\
\hline Actual weight coefficient & 106.60 & 8.21 \\
\hline \multicolumn{3}{|l|}{$q \mathrm{D} \times \circlearrowleft^{\top} \mathrm{P}$} \\
\hline Average value for the herd & 9.27 & 71.82 \\
\hline Heredity coefficient & 0.16 & 0.30 \\
\hline Selection effect & 0.21 & 1.82 \\
\hline Genetic variability & 0.20 & 3.28 \\
\hline Weighing coefficient for a trait, $\%$ & 65.25 & 34.75 \\
\hline Actual weight coefficient & 307.23 & 19.048 \\
\hline \multicolumn{3}{|l|}{ 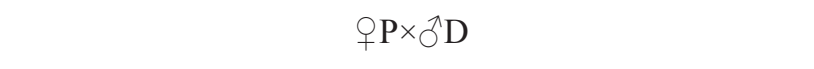 } \\
\hline Average value for the herd & 9.10 & 62.98 \\
\hline Heredity coefficient & 0.16 & 0.30 \\
\hline Selection effect & 0.03 & 2.23 \\
\hline Genetic variability & 0.26 & 2.40 \\
\hline Weighing coefficient for a trait, $\%$ & 11.89 & 88.11 \\
\hline Actual weight coefficient & 371.47 & 39.58 \\
\hline
\end{tabular}


in the group $q \mathrm{WL} \times{ }^{1} \mathrm{WL}$ to $63.09 \%$ in pigs of the group $\rightarrow \mathrm{P} \bigcirc^{\lambda} \mathrm{D}$.

The selection indexes for the evaluation of pigs by the reproductive ability were estimated, the index $\mathrm{J}_{1}$ looks as follows for interbred combinations:

$$
\begin{aligned}
& \mathrm{J}_{1(+\mathrm{WL} \times \delta \mathrm{WL})}=188.94 \times\left(\mathrm{x}_{1}-10.58\right)+13.14 \times\left(\mathrm{x}_{2}-76.63\right) \\
& \mathrm{J}_{1((\mathrm{WL} \times \delta \mathrm{L})}=106.60 \times\left(\mathrm{x}_{1}-10.36\right)+8.21 \times\left(\mathrm{x}_{2}-61.50\right) \\
& \mathrm{J}_{1\left(+\mathrm{D} \times \delta^{\lambda} \mathrm{P}\right)}=307.234 \times\left(\mathrm{x}_{1}-9.27\right)+19.048 \times\left(\mathrm{x}_{2}-71.82\right) \\
& \mathrm{J}_{1(+\mathrm{P} \times \delta \mathrm{D})}=371.47 \times\left(\mathrm{x}_{1}-9.10\right)+39.58 \times\left(\mathrm{x}_{2}-62.98\right)
\end{aligned}
$$

\begin{tabular}{|c|c|c|}
\hline Index & $\begin{array}{c}\text { Age of } \\
\text { reaching } \\
\text { the live } \\
\text { body } \\
\text { weight } \\
\text { of } 100 \mathrm{~kg} \text {, } \\
\text { days s }\end{array}$ & $\begin{array}{c}\text { Expen- } \\
\text { ses for } \\
\text { fodder } \\
\text { per } 1 \mathrm{~kg} \\
\text { of gain, } \\
\text { fodder } \\
\text { units }\end{array}$ \\
\hline \multicolumn{3}{|c|}{$\uparrow \mathrm{WL} \times{ }^{\lambda} \mathrm{WL}$} \\
\hline $\begin{array}{l}\text { Average value for the herd } \\
\text { Heredity coefficient } \\
\text { Selection effect } \\
\text { Genetic variability } \\
\text { Weighing coefficient for a trait, \% } \\
\text { Actual weight coefficient }\end{array}$ & $\begin{array}{c}183.54 \\
0.55 \\
-5.75 \\
3.86 \\
49.03 \\
8.52\end{array}$ & $\begin{array}{c}3.55 \\
0.66 \\
-0.19 \\
0.12 \\
50.97 \\
268.45\end{array}$ \\
\hline \multicolumn{3}{|l|}{$\uparrow \mathrm{WL} \times{ }^{\lambda} \mathrm{L}$} \\
\hline $\begin{array}{l}\text { Average value for the herd } \\
\text { Heredity coefficient } \\
\text { Selection effect } \\
\text { Genetic variability } \\
\text { Weighing coefficient for a trait, \% } \\
\text { Actual weight coefficient }\end{array}$ & $\begin{array}{c}182.18 \\
0.55 \\
-5.00 \\
4.55 \\
44.48 \\
8.891\end{array}$ & $\begin{array}{c}3.51 \\
0.66 \\
-0.17 \\
0.12 \\
55.52 \\
333.042\end{array}$ \\
\hline \multicolumn{3}{|l|}{$q \mathrm{D} \times{ }^{\lambda} \mathrm{P}$} \\
\hline $\begin{array}{l}\text { Average value for the herd } \\
\text { Heredity coefficient } \\
\text { Selection effect } \\
\text { Genetic variability } \\
\text { Weighing coefficient for a trait, \% } \\
\text { Actual weight coefficient }\end{array}$ & $\begin{array}{c}173.96 \\
0.40 \\
-2.38 \\
3.15 \\
30.98 \\
12.99\end{array}$ & $\begin{array}{c}3.42 \\
0.40 \\
-0.13 \\
0.08 \\
69.02 \\
539.90\end{array}$ \\
\hline \multicolumn{3}{|l|}{ 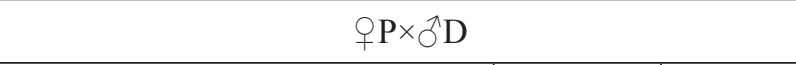 } \\
\hline $\begin{array}{l}\text { Average value for the herd } \\
\text { Heredity coefficient } \\
\text { Selection effect } \\
\text { Genetic variability } \\
\text { Weighing coefficient for a trait, \% } \\
\text { Actual weight coefficient }\end{array}$ & $\begin{array}{c}177.24 \\
0.40 \\
-2.14 \\
2.59 \\
34.37 \\
16.09\end{array}$ & $\begin{array}{c}3.43 \\
0.40 \\
-0.09 \\
0.06 \\
65.63 \\
704.82\end{array}$ \\
\hline
\end{tabular}

Table 2. Selective-genetic parameters in the estimation of finishing traits of progeny $(n=200)$
The comparative analysis of the evaluation of productivity of sows confirmed that high reproductive ability in terms of all the indices was demonstrated by sows of the group $\bigcirc \mathrm{WL} \times{ }^{\lambda} \mathrm{WL}$, and sows on the combination $+\mathrm{WL} \times \overbrace{}^{\lambda} \mathrm{L}$.

The traits of fattening and meat productivity of pigs are determined by the amount and quality of meat, obtained from them. It is important to produce maximally possible volumes in the shortest period of time. High gains become the prerequisite of success on this way. Thus, while estimating the fattening productivity, it is relevant to pay attention to average daily gains and expenses for fodder.

The evaluation of fattening traits of the progeny involves the index $\mathrm{J}_{2}$ :

$$
\begin{aligned}
& \mathrm{J}_{2((\mathrm{WL} \times \delta \mathrm{WL})}=8.52 \times\left(183.54-\mathrm{x}_{1}\right)+268.45 \times\left(3.55-\mathrm{x}_{2}\right) \\
& \mathrm{J}_{2((\mathrm{WL} \times \delta \mathrm{L})}=8.89 \times\left(182.18-\mathrm{x}_{1}\right)+333.04 \times\left(3.51-\mathrm{x}_{2}\right) \\
& \mathrm{J}_{2(+\mathrm{D} \times \delta \mathrm{P})}=12.99 \times\left(173.96-\mathrm{x}_{1}\right)+539.90 \times\left(3.42-\mathrm{x}_{2}\right) \\
& \mathrm{J}_{2(9 \mathrm{P} \times \delta \mathrm{D})}=16.09 \times\left(177.24-\mathrm{x}_{1}\right)+704.82 \times\left(3.43-\mathrm{x}_{2}\right)
\end{aligned}
$$

To evaluate fattening and meat qualities of the progeny, the method of index selection used the index $\mathrm{J}_{3}$, which included quality indices of meat and criteria of fattening productivity:

$$
\begin{aligned}
& \mathrm{J}_{3\left(\mathrm{P} W \mathrm{WL} \times \delta^{3} \mathrm{WL}\right)}=13.35 \times\left(180.25-\mathrm{x}_{1}\right)+141.37 \times(3.55- \\
& \left.-\mathrm{x}_{2}\right)+5.30 \times\left(21.75-\mathrm{x}_{3}\right)+5.33 \times\left(33.93-\mathrm{x}_{4}\right) \\
& \mathrm{J}_{3(\mathrm{PLL} \times \partial \mathrm{L})}=3.51 \times\left(180.25-\mathrm{x}_{1}\right)+291.83 \times\left(3.55-\mathrm{x}_{2}\right)+ \\
& +10.84 \times\left(20.50-\mathrm{x}_{3}\right)+12.39 \times\left(35.18-\mathrm{x}_{4}\right) \\
& \mathrm{J}_{3(+\mathrm{D} \times\langle\mathrm{P})}=3.13 \times\left(175.755-\mathrm{x}_{1}\right)+316.51 \times\left(3.50-\mathrm{x}_{2}\right)+ \\
& +11.80 \times\left(17.75-x_{3}\right)+9.14 \times\left(39.95-x_{4}\right) \\
& \mathrm{J}_{3\left(\mathrm{P} \times{ }^{\gamma} \mathrm{D}\right)}=3.94 \times\left(178.25-\mathrm{x}_{1}\right)+534.64 \times\left(3.50-\mathrm{x}_{2}\right)+ \\
& +12.85 \times\left(16.25-\mathrm{x}_{3}\right)+3.70 \times\left(40.33-\mathrm{x}_{4}\right)
\end{aligned}
$$

The estimation of four-way progeny by selection indexes allowed ranging them depending on the level of productivity with the consideration of genotype and selecting the most efficient parental forms. The evaluation of the reproductive ability involved the indexes, developed for the maternal form $\bigcirc \mathrm{WL} \times \widehat{\partial} \mathrm{WL}$ and $q \mathrm{WL} \times \delta^{\lambda} \mathrm{L}$, and that of fattening and meat traits of the progeny - indexes, developed for local boars $\not \mathrm{D} \times \diamond^{\lambda} \mathrm{P}$ and $\odot \mathrm{P} \times{ }^{\lambda} \mathrm{D}$.

Ranging of animals by the value of indexes allowed calculating the minimal target limits at different intensity of selection with the purpose of selecting boars and sows with anticipated indices of productivity for further use in pork production. The results of estimates at different percentage of selection are presented in Table 4. 
At $20 \%$ selection, the minimal value of the reproductive ability index for the control group was 238.7 points. The animals of group $q(\mathrm{WL} \times \mathrm{L}) \times$ $\times \partial^{\lambda}(\mathrm{D} \times \mathrm{P})$ and $\phi(\mathrm{WL} \times \mathrm{L}) \times \partial^{\lambda}(\mathrm{P} \times \mathrm{D})$ had 369.16 and 264.60 points respectively. A White Large sow with the index $J=292.19$ points corresponded to the set target limit. The minimal target value of multiple pregnancy of a sow at this level of selection was 12 animals, and the mass of pen at the moment of weaning was $78.50 \mathrm{~kg}$. In the group $\odot(\mathrm{WL} \times \mathrm{L}) \times \widehat{\partial}(\mathrm{D} \times \mathrm{P})$ the minimal value of the index of reproductive ability was met by a sow $\bigcirc \mathrm{WL} \times \overbrace{}^{\lambda} \mathrm{L}$ with the index $\mathrm{J}=530.02$ points with multiple pregnancy of 12 animals, and the mass of pen at the moment of weaning of $104.80 \mathrm{~kg}$. In the combination $q(\mathrm{WL} \times \mathrm{L}) \times \widehat{\partial}(\mathrm{P} \times \mathrm{D})$ the sows with index values $\mathrm{J}=434.76$ and $\mathrm{J}=269.86$ points were characterized by the productivity indices at the level of 11 animals and $86.10 \mathrm{~kg}$.

It is reasonable to use the sows, which correspond to the estimated target limits by the indices of reproductive abilities at the set level, while crossing the suggested combinations.

The minimal target limit while selecting sires by the fattening traits of progeny within the $20 \%$ selection was from 50.57 to 255.65 points. Therefore, a group of purebred animals included 8 animals, the group $q(\mathrm{WL} \times \mathrm{L}) \times \hat{\sigma}(\mathrm{D} \times \mathrm{P})-9$ animals, and $\rho(\mathrm{WL} \times \mathrm{L}) \times$ $\times \widehat{O}(\mathrm{P} \times \mathrm{D})-13$ animals. Taking the obtained data into consideration, it is reasonable to select White Large boars, the progeny of which reached the weight of 100

Table 3. Selective-genetic parameters in estimating finishing and meat traits of progeny $(n=16)$

\begin{tabular}{|c|c|c|c|c|}
\hline Index & $\begin{array}{c}\text { Age of reaching } \\
\text { the live } \\
\text { bodyweight } \\
\text { of } 100 \mathrm{~kg},\end{array}$ & $\begin{array}{l}\text { Fodder expenses, } \\
\text { fodder units }\end{array}$ & $\begin{array}{l}\text { Fat thickness, } \\
\text { mm }\end{array}$ & $\begin{array}{l}\text { Area of "loin } \\
\text { eye", sq.cm }\end{array}$ \\
\hline \multicolumn{5}{|c|}{$q \mathrm{WL} \times \delta^{\lambda} \mathrm{WL}$} \\
\hline $\begin{array}{l}\text { Average value for the herd } \\
\text { Heredity coefficient } \\
\text { Selection effect } \\
\text { Genetic variability } \\
\text { Weighing coefficient for a trait, \% } \\
\text { Actual weight coefficient }\end{array}$ & $\begin{array}{c}180.25 \\
0.55 \\
-3.94 \\
0.53 \\
52.61 \\
13.35 \\
\end{array}$ & $\begin{array}{c}3.55 \\
0.66 \\
-0.19 \\
0.05 \\
27.14 \\
141.37 \\
\end{array}$ & $\begin{array}{c}21.75 \\
0.445 \\
-0.78 \\
1.33 \\
4.13 \\
5.30 \\
\end{array}$ & $\begin{array}{c}33.93 \\
0.48 \\
2.92 \\
1.27 \\
16.12 \\
5.53 \\
\end{array}$ \\
\hline \multicolumn{5}{|c|}{$\uparrow \mathrm{WL} \times \overbrace{}^{\wedge} \mathrm{L}$} \\
\hline $\begin{array}{l}\text { Average value for the herd } \\
\text { Heredity coefficient } \\
\text { Selection effect } \\
\text { Genetic variability } \\
\text { Weighing coefficient for a trait, \% } \\
\text { Actual weight coefficient }\end{array}$ & $\begin{array}{c}180.25 \\
0.55 \\
-3.94 \\
2.86 \\
13.83 \\
3.51 \\
\end{array}$ & $\begin{array}{c}3.55 \\
0.66 \\
-0.19 \\
0.03 \\
55.06 \\
291.83 \\
\end{array}$ & $\begin{array}{c}20.50 \\
0.445 \\
-0.22 \\
0.93 \\
2.41 \\
10.84 \\
\end{array}$ & $\begin{array}{c}35.18 \\
0.48 \\
2.32 \\
0.81 \\
28.70 \\
12.39 \\
\end{array}$ \\
\hline \multicolumn{5}{|c|}{$\phi \mathrm{D} \times{ }^{\lambda} \mathrm{P}$} \\
\hline $\begin{array}{l}\text { Average value for the herd } \\
\text { Heredity coefficient } \\
\text { Selection effect } \\
\text { Genetic variability } \\
\text { Weighing coefficient for a trait, \% } \\
\text { Actual weight coefficient }\end{array}$ & $\begin{array}{c}175.75 \\
0.40 \\
-3.10 \\
2.96 \\
9.69 \\
3.13 \\
\end{array}$ & $\begin{array}{c}3.50 \\
0.40 \\
-0.16 \\
0.03 \\
50.32 \\
316.51 \\
\end{array}$ & $\begin{array}{c}17.75 \\
0.46 \\
-0.81 \\
0.79 \\
9.50 \\
11.80\end{array}$ & $\begin{array}{c}39.95 \\
0.48 \\
3.34 \\
1.01 \\
30.49 \\
9.14 \\
\end{array}$ \\
\hline \multicolumn{5}{|c|}{$q \mathrm{P} \times{ }^{\Uparrow} \mathrm{D}$} \\
\hline $\begin{array}{l}\text { Average value for the herd } \\
\text { Average value by the leading group } \\
\text { Selection effect } \\
\text { Genetic variability } \\
\text { Weighing coefficient for a trait, \% } \\
\text { Actual weight coefficient }\end{array}$ & $\begin{array}{c}178.25 \\
171.90 \\
-2.54 \\
1.44 \\
10.00 \\
3.94\end{array}$ & $\begin{array}{c}3.50 \\
3.20 \\
-0.12 \\
0.01 \\
63.09 \\
534.64\end{array}$ & $\begin{array}{c}16.25 \\
14.00 \\
-1.04 \\
0.44 \\
13.30 \\
12.85\end{array}$ & $\begin{array}{c}40.33 \\
48.00 \\
3.68 \\
1.53 \\
13.62 \\
3.70\end{array}$ \\
\hline
\end{tabular}


Table 4. Target selection limits

\begin{tabular}{|c|c|c|c|}
\hline Selection limits, $\%$ & $q \mathrm{WL} \times \jmath^{\lambda} \mathrm{WL}$ & $q(\mathrm{WL} \times \mathrm{L}) \times \partial^{\top}(\mathrm{D} \times \mathrm{P})$ & $q(\mathrm{WL} \times \mathrm{L}) \times \widehat{\jmath}(\mathrm{P} \times \mathrm{D})$ \\
\hline \multicolumn{4}{|c|}{ Sows by reproductive traits $(n=44)$} \\
\hline $\begin{array}{l}20 \\
30 \\
40 \\
\end{array}$ & $\begin{array}{c}238.70 \\
133.73 \\
45.17 \\
\end{array}$ & $\begin{array}{l}369.16 \\
292.05 \\
226.98 \\
\end{array}$ & $\begin{array}{l}264.60 \\
207.24 \\
158.85 \\
\end{array}$ \\
\hline $\begin{array}{l}20 \\
30 \\
40 \\
\end{array}$ & $\begin{array}{r}50.57 \\
22.56 \\
-1.08 \\
\end{array}$ & $\begin{array}{l}255.65 \\
226.63 \\
155.94 \\
\end{array}$ & $\begin{array}{l}218.57 \\
184.61 \\
155.94 \\
\end{array}$ \\
\hline \multicolumn{4}{|c|}{ Boars by fattening and meat traits of progeny $(n=16)$} \\
\hline
\end{tabular}

$\mathrm{kg}$ in at least 173 days with the expenses for fodder of 3.3 fodder units, for further usage. The productivity indices data for two-breed boars $\bigcirc \mathrm{D} \times{ }^{\lambda} \mathrm{P}$ and $\uparrow \mathrm{P} \times \lesssim \mathrm{D}$ should be at least 164 days, 3.1 fodder units and 167 days, 3.3 fodder units respectively.

According to the indices of the index estimation by meat and fattening traits, it is reasonable to select White Large boars, the progeny of which reached the weight of $100 \mathrm{~kg}$ at least after 170 days with the expenses for fodder of 3.6 fodder units, fat thickness of $27 \mathrm{~mm}$, the area of "loin eye" of 30.5 sq.cm. These productivity indices of the progeny for boars of the combination $\$ \mathrm{D} \times{ }^{1} \mathrm{P}$ should be at least 178 days, 3.1 fodder units, $15 \mathrm{~mm}, 44.5$ sq. cm. respectively. As for the animals of

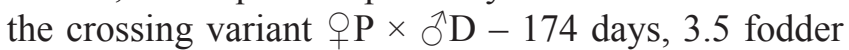
units, $14 \mathrm{~mm}, 39$ sq.cm.

\section{CONCLUSIONS}

Index evaluation of pigs in the crossing, based on the indices of reproductive, fattening, finishing and meat traits of the progeny, allowed ranging them by the index values. The estimates allowed setting minimal target limits of selecting animals and optimizing the selection of parental pairs with estimated productivity: in case of $20 \%$ selection by multiple pregnancy with at least 11 animals, the area of "loin eye" $30.5-44.5$ sq.cm. It would be reasonable to select the animals, the productivity of progeny of which is above the determined limit, for further breeding from 238.70 to 606.94 points. This selection should be performed in each specific population.

\section{ACKNOWLEDGMENT}

The authors would like to thank the staff and the head of Freedom Farm Bacon Limited Liability Company, Oleksandr Pokhvalenko.

This article does not relate to any studies using humans and animals as investigation subjects.

Conflict of interests. The authors deny any conflict of interests.

Financing. This study did not receive any specific grant from the financing institutions in state, commercial or non-commercial sectors.

\section{Індексна оцінка свиней та встановлення цільових меж відбору}

\section{В. Г. Пелих, С. В. Ушакова, Н. Л. Пелих}

Державний вищий навчальний заклад «Херсонський державний аграрний університет»

73006, м. Херсон, вул. Стрітенська, 23 e-mail: ushakovasvetlan@ukr.net

Мета. Розрахувати мінімальні межі відбору тварин для отримання високих показників продуктивності. Методи. Загальноприйняті методики оцінки відтворювальної здатності свиноматок, відгодівельних та м'ясо-сальних якостей нащадків. Селекційні індекси будували методом нормованих відхилень за М.В. Михайловим. Цільові межі відбору тварин визначали з використанням таблиці Ле Роу. Результати. Розраховані селекційні індекси із ваговими коефіцієнтами ознак для кожної групи свиней на основі яких встановлені мінімальні межі за різної інтенсивності відбору. Оцінка помісних нащадків за селекційним індексами дозволила ранжувати їх у 
залежності від рівня продуктивності з урахуванням генотипу. При 20 \% відборі мінімальне значення індексу відтворювальної здатності для контрольної групи становило 238,70 балів. Мінімальна цільова межа, при відборі кнурів за відгодівельними якостями нащадків, у межах відбору 20 \% становила від 50,57 до 255,65 балів.

Висновки. Індексна оцінка свиней у схрещуванні дала змогу ранжувати їх за величиною індексів. Встановлено мінімальні цільові межі відбору тварин і оптимізовано відбір батьківських пар з прогнозованою продуктивністю : при 20\%-ному відборі за багатоплідністю не менше 11 голів, площею «м'язового вічка» 30,5-44,5 см². Для подальшого використання доцільно відбирати тварин, продуктивність потомків яких вище встановленої межі від 238,70 до 606,94 балів.

Ключові слова: межі відбору, п’єтрен, дюрок, селеційний індекс відтворювальної здатності, селекційний індекс відгодівельних якостей, багатопородне схрещування, м'ясна продуктивність.

\section{Индексная оценка свиней и определение целевых границ отбора}

В. Г. Пелых, С. В. Ушакова, Н. Л. Пелых

Государственное высшее учебное заведение «Херсонский государственный аграрный университет» 73006, г. Херсон, ул. Стретенская, 23

e-mail: ushakovasvetlan@ukr.net

Цель. Рассчитать минимальные границы отбора животных для получения высоких показателей продуктивности. Методы. Общепринятые методики оценки воспроизводительной способности свиноматок, откормочные и мясо-сальные качества потомков. Селекционные индексы строили методом нормированных отклонений по М.В. Михайлову. Целевые границы отбора животных определяли с использованием таблицы Ле Роу. Результаты. Рассчитаны селекционные индексы с весовыми коэффициентами признаков для каждой группы свиней, на основе которых установлены минимальные границы при различной интенсивности отбора. Оценка помесных потомков по селекционным индексами позволила ранжировать их в зависимости от уровня продуктивности с учетом генотипа. При $20 \%$ отборе минимальное значение индекса воспроизводительной способности для контрольной группы составило 238,70 баллов. Минимальная целевая граница, при отборе хряков по откормочным качествам потомков, в рамках отбора $20 \%$ составляла от 50,57 до 255,65 баллов. Выводы. Индексная оценка свиней в скрещивании позволила ранжировать их по величине индексов. Установлены минимальные целевые границы отбора животных и оптимизирован отбор родительских пар с прогнозируемой продуктивностью: при 20\%-ном отборе по многоплодию не менее 11 голов, площадью «мышечного глазка» $30,5-44,5$ см$^{2}$. Для дальнейшего использования целесообразно отбирать животных, продуктивность потомков которых выше установленной границы от 238,70 до 606,94 баллов.

Ключевые слова: границы отбора, пьетрен, дюрок, селекционной индекс воспроизводительной способности, селекционной индекс откормочных качеств, многопородное скрещивание, мясная продуктивность.

\section{REFERENCES}

1. Krupa E, Žáková E, Krupová Z. Evaluation of Inbreeding and Genetic Variability of Five Pig Breeds in Czech Republic. Asian-Australasian J. Anim. Sci. (AJAS). 2015;28(1):25-36. doi: 10.5713/ajas.14.0251.

2. Abell CE, Fernando RL, Serenius TV, Rothschild MF, Gray KA, Stalder KJ. Genetic relationship between purebred and crossbred sow longevity. J. Anim. Sci. Biotech. 2016;7:51. doi: 10.1186/s40104-016-0112-x.

3. Alfonso L. Impact of incorporating greenhouse gas intensities in selection indexes for sow productivity traits. Livestock sci. 2019;219:57-61. doi: 10.1016/j. livsci.2018.11.016.

4. Ali BM, Bastiaansen JWM, de Mey Y, Lansink AGJMO. Response to a selection index including environmental costs and risk references of producers. J. Anim. Sci. 2019;97(1):156-71. doi: 10.1093/jas/sky400.

5. Cheng J, Newcom DW, Schutz MM, Cui Q, Li B, Zhang H, Schinckel AP. Evaluation of current United States swine selection indexes and indexes designed for Chinese pork production. Prof. Anim. Sci. 2018;34(5):474-87. https:// doi.org/10.15232/pas.2018-01731.

6. Getya A, Dodenhoff J. Use of BLUP-method for selection merit evaluation in Ukrainian pig production. $\mathrm{Zb}$. nauk. prats Bilotserk. derzh. agrar. un-t, 2010;3(72):52-4.

7. Nielsen SS, Denwood MJ, Forkman B, Houe $H$. Selection of Meat Inspection Data for an Animal Welfare Index in Cattle and Pigs in Denmark. 2017;7(12):E94. doi: 10.3390/ani7120094.

8. Stas NM, Ellis M, Grohmann NS, Schwab CR, Shull CM, Ewing K. 030 Effect of swine sire line and selection index category on wean-to-finish growth performance and carcass characteristics. J. Anim. Sci. 2017:95(2):14. doi:10.2527/asasmw.2017.030.

9. Sánchez JP, Ragab M, Quintanilla R, Rothschild MF, Piles $M$. Genetic parameters and expected responses to selection for components of feed efficiency in a Duroc pig line. Genet. Sel. Evol. 2017;49:86. doi: 10.1186/ s12711-017-0362-x.

10. Song H, Zhang J, Jiang Y, Gao H, Tang S, Mi S, Yu F, Meng $Q$, Xiao $W$, Zhang $Q$, Ding $X$. Genomic prediction for growth and reproduction traits in pig using an admixed reference population. J. Anim. Sci. 2017;95(8):3415. doi:10.2527/jas2017.1656. 
11. Littmann E. Schweinezucht und Schweineproduktion: Unterrichts-und Beratungshilfe. LfL, 2006.

12. Welsh CS, Stewart TS, Schwab C, Blackburn HD. Pedigree analysis of 5 swine breeds in the United States and the implications for genetic conservation. J. Anim. Sci. 2010;88(5):1610-8. doi: 10.2527/jas.2009-2537.

13. Mathur P, Vogelzang $R$, Mulder H, Knol E. Genetic selection to enhance animal welfare using meat inspection data from slaughter plants. Animals. 2018;8(2):16. doi: 10.3390/ani8020016.

14. Suslina EN. A new breed of Duroc swine, Kirovsky, was created. Perspektivnoe svinovodstvo: Teoria i praktika. 2011;(3):12. [in Russian].

15. Svinarev IY, Goncharov AYu. Analysis of reproductive qualities of purebred Landrace breed sows and hybrids
F1 (Yorkshire $\times$ Landrace). Politematicheskiy setevoy elektronnyi nauch. zhurn. Kuban. Gos. Agrar. un-ta. 2011;(70):688-97.

16. Pat. BY 17677 Republic of Belarus, MPK A 01K 67/02 (2006.01). Method of evaluating the compatibility of parental pairs of swine by meat-fattening traits of progeny. I.P. Sheiko, N.A. Loban, O.Ya. Vasyliuk, I.S. Malikov; applicant and patent holder: Republican unitary enterprise "Scientific-practical center of the National Academy of Sciences of Belarus on animal breeding". No. a.s. 20100713; appl. 11.05.10; publ. 30.10.13.

17. Mikhailov NV, Kosteilev EV, Svinarev IY, Tretiakova $O L$. Application of software in selection of animals. Politematicheskiy setevoy elektronnyiy nauch zhurn. Kuban. Gos. Agrar. un-ta. 2013;(85):1-14. 